\title{
ENDURANCE TRAINING INDUCES STRUCTURAL AND MORPHOQUANTITATIVE CHANGES IN RAT VAGUS NERVE
}

\author{
TREINAMENTO DE ENDURANCE INDUZ ALTERAÇÕES ESTRUTURAIS E MORFOQUANTITATIVAS \\ NO NERVO VAGO DE RATOS
}

Original Article

ARTIGo ORIGINAL

Artículo Original

\author{
ENTRENAMIENTO DE ENDURANCE INDUCE A ALTERACIONES ESTRUCTURALES Y \\ MORFOCUANTITATIVAS EN EL NERVIO VAGO DE RATONES
}

\author{
Eduardo Pianca1,3 \\ (Fisioterapeuta) \\ Walter Krause Neto ${ }^{1}$ \\ (Educador Físico) \\ Tania Christina Pithon-Curi² \\ (Educador Físico) \\ Eliane Florencio Gama' \\ (Fisioterapeuta) \\ Alexandre Sabbag \\ (Fisioterapeuta) \\ Romeu Rodrigues de Souza ${ }^{4}$ \\ (Médico)
}

\section{Universidade São Judas Tadeu, Department of Physical Education, São Paulo, SP, Brazil. \\ 2. Universidade Cruzeiro do Sul, Department of Physical Education, São Paulo, SP, Brazil. \\ 3. Universidade de Guarulhos, Department of Physiotherapy, São Paulo, SP, Brazil. \\ 4. Universidade São Judas Tadeu, Department of Physical Education, São Paulo, SP, Brazil and Universidade de São Paulo, Department of Anatomy, \\ São Paulo, SP, Brazil.}

\section{Correspondence:}

Walter Krause Neto, Universidade São Judas Tadeu, Unidade Mooca, Rua Taquari, 546, Mooca. 03166-000, São Paulo, SP, Brasil. wild_krause@hotmail.com.

\begin{abstract}
Introduction: Many nervous system tissues and cells suffers positive changes when faced to exercise training. However, data on vagus nerve adaptation from exercise-induced study is absent. Objective: To analyze the effect of an endurance training on the vagus nerve morphology of rats. Methods: Wistar rats (6 months of age) were divided into two groups: control group ( $(\mathrm{C}, \mathrm{n}=8)$, and aerobic trained group (AT, $n=8$ ). AT was submitted to a treadmill training program of five times per week during 12 weeks. The maximum speed stipulated in the training protocol corresponded to $60 \%$ of the mean maximum intensity achieved by the group in the test of maximum effort. Results: Twelve weeks of treadmill training resulted in left ventricular hypertrophy in the AT group compared to CG. There was a significant increase in the area of both the myelinated and unmyelinated axons, and in the area of myelin sheath with training. The number of neurotubules and neurofilaments in myelinated fibers of aerobic trained group was significantly greater than $C G(p \leq 0.05)$. Conclusion: Endurance training promoted significant increase in morphometric parameters of the vagus nerve in the same way it affect somatic nerves.
\end{abstract}

Keywords: training, running, nerve tissue.

\section{RESUMO}

Introdução: Muitos tecidos e células do sistema nervoso sofrem alterações positivas quando se defrontam com o treinamento físico. Entretanto, dados sobre a adaptação do nervo vago decorrente de estudos com exercício físico são ausentes. Objetivo: Analisar o efeito do treinamento de endurance sobre a morfologia do nervo vago de ratos. Métodos: Ratos Wistar (6 meses de idade) foram divididos em dois grupos: grupo controle (GC, $n=8$ ), e grupo com treinamento aeróbico (TA, $n=8$ ). O grupo TA foi submetido a um programa de treinamento em esteira rolante, cinco vezes por semana durante 12 semanas. A velocidade máxima estipulada no protocolo de treinamento correspondeu a $60 \%$ da intensidade média alcançada pelo grupo no teste de esforço máximo. Resultados: Doze semanas de treinamento em esteira rolante resultou em hipertrofia ventricular no grupo TA em comparação ao GC. Foi verificado um aumento significativo na área de ambos axônios mielinizados e não mielinizados, e na área da bainha de mielina com treinamento. O número de neurotúbulos e neurofilamentos das fibras mielinizadas foi significativamente maior no grupo com treinamento aeróbico em comparação ao GC ( $p \leq 0,05)$. Conclusão: O treinamento de endurance promoveu aumento significativo nos parâmetros morfométricos do nervo vago da mesma forma que isto afeta os nervos somáticos.

Palavras-chave: treinamento, corrida, tecido nervoso.

\section{RESUMEN}

Introducción: Muchos tejidos del sistema nervioso y células sufren cambios positivos cuando se enfrentan con el entrenamiento físico. Sin embargo, los datos sobre la adaptación del nervio vago que resulta de los estudios con el ejercicio son ausentes. Objetivo: Analizar el efecto del entrenamiento de endurance en la morfología del nervio vago de ratones. Método: Ratones Wistar (6 meses de edad) se dividieron en dos grupos: grupo control (GC, $n=8)$ y grupo con entrenamiento aeróbico (TA, $n=8)$. El grupo TA se sometió a un programa de entrenamiento sobre una cinta de correr cinco veces por semana durante 12 semanas. La velocidad máxima estipulada en el protocolo de entrenamiento correspondió al $60 \%$ de la intensidad media máxima alcanzada por el grupo en la prueba de ejercicio máximo. Resultados: Doce semanas de entrenamiento en una cinta resultaron en la hipertrofia ventricular en el grupo TA en comparación con GC. Se obtuvo un aumento significativo en el área de ambos axones mielinizados y no mielinizados, y en el área de la vaina de mielina con entrenamiento. El número de neurotúbulos y neurofilamentos de fibras mielinizadas fue significativamente mayor en el grupo con entrenamiento aeróbico en comparación con GC $(p=0,05)$. Conclusión: El entrenamiento de endurance causó un aumento significativo en los parámetros morfométricos del nervio vago en la misma forma en que afecta a los nervios somáticos.

Palabras clave: entrenamiento, carrera, tejido nervioso. 


\section{INTRODUCTION}

The quantitative changes promoted by endurance training on somatic nerves are well established. There is an increase in the area of myelin sheath (MA), unmyelinated axons (UA) and myelinated fibers. ${ }^{1,2,3}$

However, quantitative studies on the beneficial effects of endurance training on visceral nerves are scarce and these studies are referred especially to functional aspects of the nerves rather than the morphological or quantitative aspects. ${ }^{4-8}$ Goldsmith et al. ${ }^{4}$ and lellano et al. ${ }^{5}$ demonstrated that moderate endurance exercise increases the vagal tonus and diminishes the action of the sympathetic nerve, protecting the heart.

The vagus nerve is one of the most important visceral nerve $e^{9-11}$ controlling the function of thoracic and abdominal viscera and maintaining homeostasis under changing environmental and behavioral conditions. ${ }^{11-14}$ It contains afferent and efferent myelinated and unmyelinated axons, involved in vital reflexes such as cardiovascular, pulmonary and gastrointestinal input to and from the central nervous system. ${ }^{15-17}$ It contains also a number of collagen fibers in the interstitial space among nerve fibers. ${ }^{18}$

In this study we have used electron microscopy to check the influence of aerobic training on quantitative aspects from myelinated and unmyelinated fibers of the vagus nerve using the Wistar rat as an animal model. The effects of treadmill training on vagus nerve structure were assessed by comparison of two sets of rats: sedentary animals of the same age and rats of the same body weight as the exercised cohort. Therefore, this study aimed to analyze the effect of endurance training on the vagus nerve morphology and ultrastructure of rats

\section{MATERIALS AND METHODS}

Male Wistar rats (6 months of age) were acclimated during one week before the initiation of the experiment. It received commercial food and water ad libitum, and housed in a light- and temperature-controlled room. After acclimatization, rats were randomly divided into two groups: control group (CG) $(n=8)$ and aerobic trained group (AT) $(n=8)$, both sacrificed with 9 months of age.

\section{Training protocol}

AT group was submitted to a treadmill exercise training program according to previously described. ${ }^{19}$ Before training, rats were familiarized with the equipment by running for $15 \mathrm{~min} /$ day during 5 days. After these, rats performed the protocol 5 days/week during 12 weeks, with speed and duration progressively increased. AT rats began training at $12 \mathrm{~m} / \mathrm{min}$ for $15 \mathrm{~min} /$ day. The speed was progressively increased such that by the end of the second week, the rats were running at $16 \mathrm{~m} / \mathrm{min}$ for $60 \mathrm{~min} /$ day, 5 days/week. The duration was maintained but speed was increased 3-4 m/min each week. At week 10 , the animals ran at $32 \mathrm{~m} / \mathrm{min}$ for $60 \mathrm{~min} /$ day and this program was maintained until rats were sacrificed by the end of the protocol. Just to pass it by, animals from CG were placed on the treadmill one time per week for $10 \mathrm{~min} /$ session (speed $=5 \mathrm{~m} / \mathrm{min}$ ) to provide an equivalent amount of stress. All animals were weighted one/month from beginning to end. All experimental procedures were approved by the Institutional Animal Care and Use Committee of Universidade São Judas Tadeu, São Paulo, Brasil.

At the end of the experiment, the rats were anaesthetized with sodium pentobarbital (60 mg/Kg, i.p.) and then euthanized. The hearts were excised in diastole, heparinized and the myocardium was perfused through the aorta using a $2.5 \%$ glutaradehyde diluted in $0.1 \mathrm{M}$ cacodylate buffer. The left ventricle, including the septum, was then isolated and weighted. A perpendicular section to the long axis of the left ventricle including the entire thickness of the left ventricle (LV) was cut at the level of the papillary muscles. Then, the thickness of the LV wall and internal diameter were obtained by measuring the widths of four of uniformly spaced sites along the length of each section using a computerized program (Axio Vision, Carl Zeiss AG, Jena Germany).

Under a dissecting microscope, the vagus nerve trunk was exposed at mid-cervical level and bathed in fixative solution ( $2.5 \%$ glutaraldehyde - $2 \%$ paraformadehyde in cacodylate buffer $0.1 \mathrm{M}, \mathrm{pH}$ 7.4). Segments $5 \mathrm{~mm}$ in length of the vagus nerve were harvested, fixed $\left(4 \mathrm{~h}, 4^{\circ} \mathrm{C}\right)$ and rinsed in buffer. Nerve segments were then cut, post-fixed in osmium tetroxide $\left(2 \%, 2 \mathrm{~h}, 4^{\circ} \mathrm{C}\right)$, dehydrated through a graded series of ethanol and contrasted with uranyl acetate. In order to obtain transverse sections, the nerve was oriented longitudinally in a silicone mold and embedded in Araldite.

To determine the transversal section area of the nerve, semi-thin sections of $0.3 \mu \mathrm{m}$ were obtaining, stained in $1 \%$ toluidine blue and evaluated with a light microscope combined with an image analyzing system (Axion Vision, Zeiss).

The density of Schwann cells (number/ $\mu \mathrm{m}^{2}$ ), the cross-sectional area of myelinated axon $\left(\mu \mathrm{m}^{2}\right)$ and the thickness of myelin sheath $(\mu \mathrm{m})$ in each section was obtained directly on electron micrographs at a magnification of $x 4000$ on 10 fields chosen by systematic random sampling of squares ${ }^{13}$, covering representative parts of the nerve profile. The ratio of axon diameter to the total fiber diameter ( $\mathrm{g}$ ratio diameter - a measure of degree of myelination) was also calculated for the two groups.

Only myelinated axon (MA) and Schwann cell (SCS) whose contour was completely within each field was counted. In addition, the number of unmyelinated axons (UMs) present in each section was obtained with electron micrographs at a magnification of x6000 on 10 randomly chosen fields per animal. The density of MA (number/ $\mu \mathrm{m}^{2}$ ) of the nerve was also determined.

Five electron photomicrographs from myelinated fibers per animal were taken (x50) and neurotubules and neurofilaments were counted over a representative unit rectangular sampling area $\left(2.16 \mu \mathrm{m}^{2}\right)$.

\section{Statistical analysis}

The results were expressed as means \pm standard deviation. Between groups data was compared statistically by ANOVA and Tukey's test for group comparisons. The level of significance was set at $p \leq 0.05$ (figure 1).

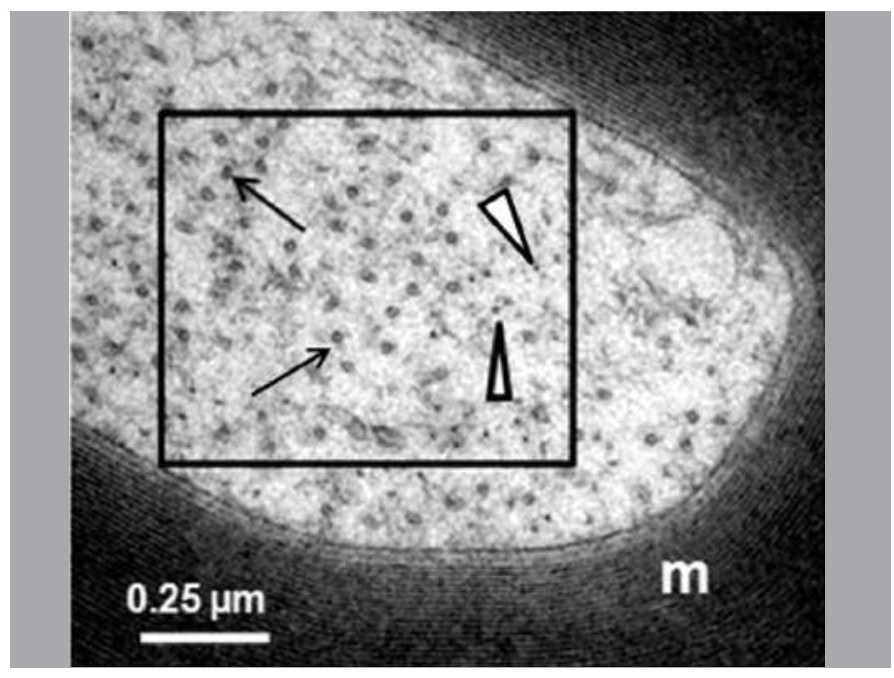

Figure 1. Electron microscopic photomicrograph showing the unit rectangular sampling area $\left(2.16 \mu \mathrm{m}^{2}\right)$, from a myelinated fiber in the vagus nerve, for counting neurotubules (arrows) and neurofilamentos (arrowheads). m-Myelin sheath. 


\section{RESULTS}

\section{Effects of endurance training on body weight and cardiac hypertrophy.}

The ratio Left ventricle weight-body weight (LVW/BW) increased $19 \%$ in AT group $(p<0.01)$ compared to the CG group. The LV internal diameter increased $20 \%$ in the AT group ( $p<0.05$ ) compared with the CG group. No significant difference was observed in the body weight and LV wall thickness between the CG and AT groups (table 1).

Table 1. Body weight (BW), Left ventricle weight/body weight (LVW/BW) ratio, Left ventricle wall thickness and Left ventricle internal diameter in sedentary (CG) and trained rats (AT).

\begin{tabular}{c|c|c|c}
\hline Parameter/Groups & CG & AT & p-Value \\
\hline BW $(\mathrm{g})$ & $316 \pm 11$ & $312 \pm 15$ & $>0.05$ \\
\hline LV weight/BW $(\mathrm{mg} / \mathrm{g})$ & $2.6 \pm 0.2$ & $3.1 \pm 0.1^{*}$ & $\leq 0.01$ \\
\hline LV wall thickness $(\mu \mathrm{m})$ & $2.3 \pm 0.03$ & $2.4 \pm 0.1$ & $\geq 0.05$ \\
\hline LV internal diameter $(\mu \mathrm{m})$ & $6.2 \pm 0.03$ & $7.5 \pm 0.05^{*}$ & $\leq 0.05$ \\
\hline
\end{tabular}

\section{Qualitative Morphological changes}

Photomicrographs of representative semithin sections of the vagus nerves obtained from CG and AT group rats appear in figure 2. Transverse sections from CG and AT showed nerves enveloped by a well-defined Perineurium. The endoneural space contained numerous nerve fibers and several blood vessels. The diameter of the nerve seems to be greater in AT than in CG rats.

Electron photomicrographs of cross sections of the nerves showed myelinated fibers of various diameters, intermingled with unmyelinated ones and several capillaries within the endoneural space. Other endoneural space components were Schwann cells, interstitial tissue and fibroblasts (figure 3).

The density of myelinated fibers (number/ $\mu m^{2}$ ) in CG and AT rats was $18 \pm 3$ and $17 \pm 2$, respectively. The cross-sectional area of the vagus nerve increased significantly in the trained group in relation to the CG group $(p<0.05)$. The axon diameter of myelinated axon in AT group was significantly larger than that of CG rats $(p<0.05)$. After 3

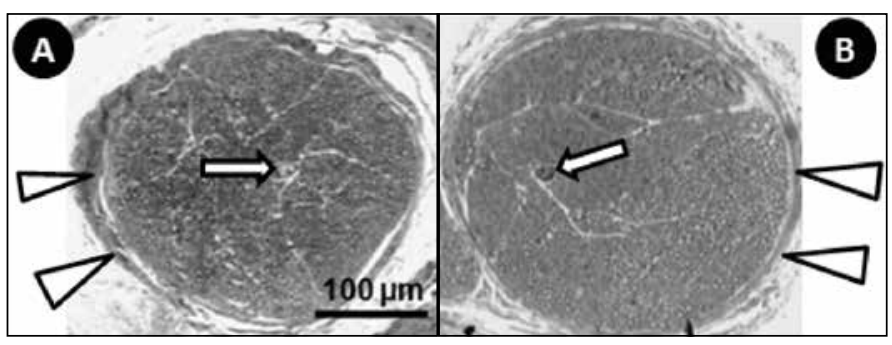

Figure 2. Semithin transverse sections of the Vagus nerves of CG (A) and AT (B) groups of rats. Note the cervical vagus nerves are enveloped by a well- defined perineurium (arrowheads). The endoneural space contains hundreds fibers and several blood vessels (arrows) accompanying the longitudinal axis of the fascicles. Diameter difference was observed between CG and AT rats. Toluidine blue stained.

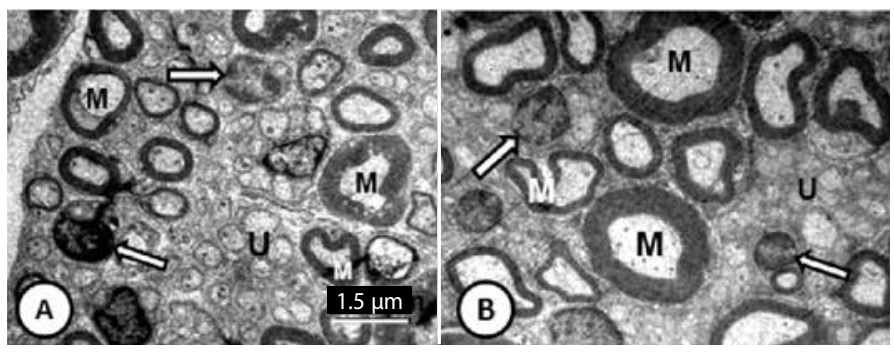

Figure 3. Electron photomicrographs of cross sections of vagus nerve from CG (A) and AT rats (B) showing a number of myelinated $(M)$ and unmyelinated $(U)$ fibers of various sizes and various nuclei of Schwann cells (arrows). months of endurance training, both, thickness of myelin sheath and of the unmyelinated axon were significantly larger than CG group $(p<0.05)$. The average value of the $g$ ratio was 0.6 for $C G$ and 0.7 for AT. However, statistical difference was not significant $(p>0.05)$. The mean number of microtubules and neurofilaments per unit area was greater in myelinated axons in the AT rats than in the controls (table 2).

Figure 4 shows the histograms for the myelinated axon diameters in the two groups of rats. Myelinated axon diameters were unimodally distributed for both groups of rats and a right-ward shift of the distribution was observed for the AT group of rats.

Table 2. Quantitative analysis of structural changes in number of fibers, axon diameter, myelin sheath sizes, $g$ ratio and number of microtubules and neurofilaments in the vagus nerve of rats from CG and AT groups.

\begin{tabular}{c|c|c}
\hline Parameter/Group & CG & AT \\
\hline Area $\left(\mu \mathrm{m}^{2}\right)$ & $0.081 \pm 0.005$ & $0.092 \pm 0.004^{*}$ \\
\hline Myelinated axon diameter $(\mu \mathrm{m})$ & $1.9 \pm 0.03$ & $2.9 \pm 0.02^{*}$ \\
\hline Myelinated sheath thickness $(\mu \mathrm{m})$ & $0.49 \pm 0.04$ & $0.58 \pm 0.03^{*}$ \\
\hline Unmyelinated axon diameter $(\mu \mathrm{m})$ & $0.61 \pm 0.03$ & $0.75 \pm 0.02^{*}$ \\
\hline g-ratio & $0.65 \pm 0.13$ & $0.71 \pm 0.1$ \\
\hline Number of microtubules/area & $23 \pm 5$ & $34 \pm 8^{*}$ \\
\hline Number of neurofilaments/area & $19 \pm 3$ & $26 \pm 6^{*}$ \\
\hline
\end{tabular}

Values area mean \pm SEM. *significantly different from CG, $p \leq 0.05$.

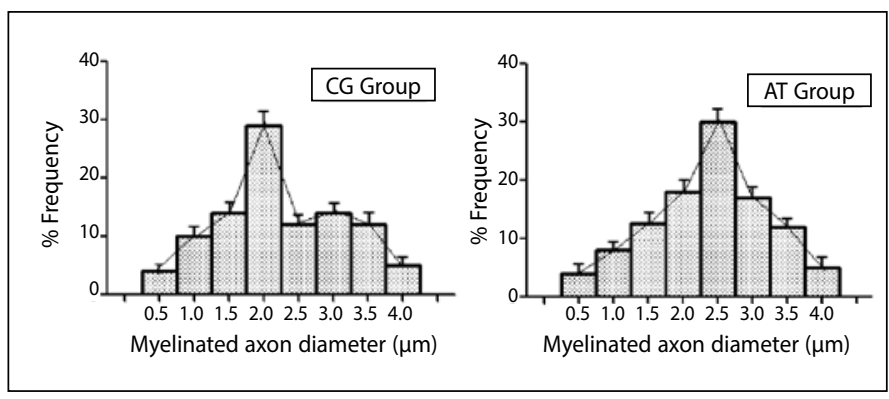

Figure 4. Histograms showing the frequency distribution of axon diameter of the vagus nerve. These histograms include all nerves measured: a total of 120 fibers of CG rats and 120 fibers in AT group of rats. Note the unimodal distribution for both groups of rats and the right-ward shift of the distribution for the AT group of rats.

\section{DISCUSSION}

There are reports on the effects of endurance training on peripheral nerves in rats, but the vagus nerve has never been investigated from this point of view. ${ }^{20,21}$ The importance of examining the effects of training on the right vagus nerve resides on the fact that the right vagus nerve innervates mainly the sinoatrial node which is of particular interest in regard to heart rate control during training.

There are two major findings in the present work. First, rats subjected to chronic endurance training for 12 weeks exhibited a significant increase in the diameter of the axon and of the myelin sheath of the vagus nerve fibers compared to sedentary controls. The diameter of the unmyelinated fibers increased significantly in trained rats. Second, an increase in the number of microtubules and neurofilaments per unit area was detected in myelinated axons from trained rats.

In the present study, no significant differences were observed between body weight of sedentary and trained rats and AT animals have larger LV internal diameter compared to CG. These results were similar to those described in the literature. ${ }^{22}$ During aerobic training, in addition to the increased cardiac output, the blood pressure increases. Consequently, the LV must adapt to both volume and pressure loads. The LV responds by increasing its internal diameter. ${ }^{23,24}$ Therefore, the aerobic-trained heart develops eccentric hypertrophy. ${ }^{25}$

The results of the present study show that in rats submitted to 
endurance training, the diameter of the axon and of the myelin sheath of the vagus nerve fibers increases. The diameter of the unmyelinated fibers also increases. Furthermore, the histograms of the frequency distribution of axon diameter of the vagus nerve showed a unimodal distribution for both groups of rats with a right-ward shift of the distribution for the AT group of rats. No significant difference was observed between the average values of the $g$ ratio for the two groups.

The quantitative nerve changes observed in the present study could be induced by the increase of the vagus nerve function promoted by training. Increase in the nerve function with training is related to factors such as increased production of growth factors and nucleic acids, which result in a series of chemical events leading to gradual increase in neuron sizes. ${ }^{26}$

The exposure to training probably induces production of proteins, lipids Brain-derived neurotrophic factor, also known as BDNF. This is a secreted protein that, in humans, is encoded by the BDNF gene. ${ }^{27}$ BDNF is a member of the "neurotrophin" family of growth factors and was the second neurotrophic factor to be characterized after nerve growth factor (NGF). These factors are found in the brain and the periphery; they support the survival of neurons and the growth of new ones. Exercise has been shown to increase the secretion of BDNF as a myokine at the mRNA and protein levels in the rodent hippocampus, suggesting the potential increase of this neurotrophin after exercise in humans. ${ }^{26}$

The present work showed correlation between the myelin sheath and the diameter of the respective axon, i.e. there was no significant difference between the groups about the $g$ ratio. This means that trai- ning promotes a similar growth in myelin sheath and axon. According to Rushton ${ }^{28}$ values between 0.6 and 0.7 would be the $g$ ratio for the best and maximum conduction velocity of a myelinated fiber but Fazan et al. ${ }^{29}$ have shown that small myelinated fibers as observed in baroreflex afferents have $\mathrm{g}$ ratios between 0.5 and 0.6.

In the present study, not all types of nerve fibers were affected by training in the same way. The increase of myelinated axon diameter by aerobic training involved particularly the medium sized axons, the small diameter nerve fibers remaining virtually largely intact. The cause is not known.

In the present study, number of neurotubules and neurofilaments per area also increased in myelinated axons from trained rats. According to Hoffman et al. ${ }^{30}$, Komiya ${ }^{31}$ and McQuarrie et al. ${ }^{32}$ an important determinant of axon size is the rate of transport of neurofilaments. It is possible that the progressive increase in the rate of neurofilament transport during training promoted an increased diameter of the axons. This hypothesis could explain the increased axonal diameter in training rats observed in this work.

\section{CONCLUSION}

In conclusion, the present work showed that endurance training is associated with significantly vagus nerve ultrastructural alterations similar to that observed in somatic nerves.

All authors have declared there is not any potential conflict of interests concerning this article.

\section{REFERENCES}

1. Bobinski F, Martins DF, Bratti T, Mazzardo-Martins L, Winkelmann-Duarte EC, Guglielmo LG, Santos AR. Neuroprotective and neuroregenerative effects of low-intensity aerobic exercise on sciatic nerve crush injury in mice. Neuroscience. 2011;194:337-48.

2. Malysz T, Ilha J, Nascimento PS, De Angelis K, Schaan BD, Achaval M. Beneficial effects of treadmill training in experimental diabetic nerve regeneration. Clinics (Sao Paulo). 2010;65(12):1329-37.

3. Soltanpour N, Santer RM. Preservation of the cervical vagus nerve in aged rats: morphometric and enzyme histochemical evidence. J. Auton. Nerv. Syst. 1996;60,93-101.

4. Goldsmith RL, Bloomfield DM, Rosenwinkel ET. Exercise and autonomic function. Coron. Artery Dis. 2000;11:129-35.

5. Iellano F, Legramante JM, Pigozzi F, Spataro A, Norbiato G, Lucini D, Pagani M. Conversion from vagal to sympathetic predominance with strenuous training in high-performance world class athletes. Circulation. 2002;105:2719-24.

6. Martins-Pinge MC. Cardiovascular and autonomic modulation by the central nervous system after aerobic exercise training. Braz J Med Biol Res. 2011;44(9):848-54.

7. Negrão CE, Moreira ED, Brum PC, Denadai MLDR, Krieger EMK. Vagal and sympathetic control of heart rate during exercise by sedentary and exercise-trained rats. Brazilian J. Med. Biol. Res. 1992;25:1045-52.

8. Yamamoto K, Miyachi M, Saitoh T, Yoshioka A, Onodera S. Effects of endurance training on resting and post-exercise cardiac autonomic control. Med. Sci. Sports Exerc. 2001;33:1496-502

9. Becker B. An 11,000-year German oak and pine dendrochronology for radiocarbon calibration, 1993. In: Stuiver M, Long A, Kra RS. Calibration Radiocarbon. Binder DK, Scharfman HE. "Brain-derived Neurotrophic Factor". Growth Factors. 2004;22(3):123-31.

10. Pereira A, Doshen J, Tanaka E, Goldstein LSB. Genetic analysis of a Drosophila microtubule-associated protein. J. Cell Biol. 1992;116:377-83.

11. Shi P, Stocker SD, Toney GM. Organum vasculosum laminae terminalis contributes to increased sympathetic nerve activity induced by central hyperosmolality Am J Physiol Regul Integr Comp Physiol. 2007;293:(6) R2279-89.

12. Migrenne S, Pairault C, Racine C, Livera G, Geloso A, Habert R. Luteinizing hormone-dependent activity and luteinizing hormone independent differentiation of rat fetal Leydig cells. Mol Cell Endocrinol. 2001;172(1-2):193

13. Journeay WS, Reardon FD, Martin CR, Kenny GP. Control of Cutaneous Vascular Conductance and Sweating During Recovery from Dynamic Exercise in Humans. J Appl Physiol. 2004;96:2207-12.

14. Wang YJ, Zhou CJ, Shi Q, Smith N, Li FT. Aging delays the regeneration process following sciatic nerve injury in rats. Journal of Neurotrauma. 2007;24:885-94.

15. Fazan VPS, Rodrigues Filho OA, Jordão CER, Moore KC. Ultrastructural morphology and morphometry of phrenic nerve in rats. Anat Rec. 2009;292:513-7.

16. Gabella G, Pease H.L. Number of axons in the abdominal vagus of the rat. Brain Res. 1973;58:465-9.
17. Fazan VPS, Lachat JJ. Qualitative and quantitative morphology of the vagus nerve in experimental Chagas' disease in rats: a light microscopy study. Am J Trop Med Hyg. 1997;57(6):672-7.

18. Alcantara ACL, Salgado HC, Fasan VPS. Morphology and morphometry of the vagus nerve in male and female spontaneously hypertensive rats. Brain Res. 2008;1 197:170-80.

19. Raab DM, Smith EL, Crenshaw TD, Thomas DP. Bone mechanical properties after exercise training in young and old rats. J Appl Physiol. 1990;68:130-4.

20. Selagzi H, Buyukakilli B, Cimen B, Yilmaz N, Erdogan S. Protective and therapeutic effects of swimming exercise training on diabetic peripheral neuropathy of streptozotocin-induced diabetic rats. J Endocrinol Invest. 2008:31(11):971-8.

21. Shokouhi G, Tubbs RS, Shoja MM, Roshangar L, Mesgari M, Ghorbanihaghjo A, Ahmadi N Sheikhzadeh F, Rad JS. The effects of aerobic exercise training on the age-related lipid peroxidation, Schwann cell apoptosis and ultrastructural changes in the sciatic nerve of rats. Life Sci. 2008;9;82(15-16):840-6.

22. Mokelke EA, Palmer BM, Cheung JY, Moore RL. Endurance training does not affect intrinsic calcium current characteristics in rat myocardium. Am J Physiol - Heart and Circulatory Physiology. 1997;273(3):H1193-7.

23. Brown L, Fenning A, Chan V, Loch D, Wilson K, Anderson B, Burstow D. Echocardiographic assessment of cardiac structure and function in rats. Heart Lung Circ. 2002;11:167-73.

24. Pluim BM, Zwinderman AH, Van der Laarse, A Van der Wall, EE. The athlete's heart: a meta-analysis of cardiac structure and function. Circulation. 2000;100:336-44.

25. Vinereanu D, Florescu N, Sculthorpe N, Tweddel, AC, Stephens MR, Fraser AG. Left ventricular long-axis diastolic function is augmented in the hearts of endurance-trained compared with strength-trained athletes. Clinical Science. 2002;103:249-57.

26. Cotman CW, Berchtold NC. "Exercise: a behavioral intervention to enhance brain health and plasticity". Trends Neurosci. 2002;25(6):295-301.

27. Maisonpierre PC, Le Beau MM, Espinosa R, Ip NY, Belluscio L, Monte SM, Squinto S, Furth ME, Yancopoulos GD. "Human and rat brain-derived neurotrophic factor and neurotrophin-3: gene structures, distributions, and chromosomal localizations". Genomics. 1991;10(3):558-68

28. Rushton WAH. A theory of the effects of fibre size in medullated nerve. J. Physiol (London). 1951;115:101-22

29. Fazan VPS, Salgado HC, Barreira AA. A descriptive and quantitative light and electron microscopy study of the aortic depressor nerve in normotensive rats. Hypertension. 1997;30:693-8.

30. Hoffman BB, Chang H, Farahbakhsh Z, Reaven, G. J. Clin. Invest. 1983; 74:1750-5.

31. Komiya Y. Slowing with age of the rate of slow axonal flow bifurcating axons of rat dorsal root ganglion cells. Brain Res. 1980;183:477-80.

32. McQuanie IG, Brady ST, Lasek RJ. Retardation in the slow axonal transport of cytoskeletal elements during maturation and aging. Neurobiol Aging. 1989;10:359-65. 